\title{
Pemberdayaan Anak Kost di Pondok Winaya Kota Serang-Banten Melalui Pelatihan Bank Sampah
}

\author{
Irwanto \\ Universitas Sultan Ageng Tirtayasa \\ Program Studi Pendidikan Vokasional Teknik Elektro, Fakultas Keguruan dan Ilmu Pendidikan \\ e-mail: irwanto.ir@untirta.ac.id
}

\begin{abstract}
In the empowerment activities carried out by the men's boarding house, Pondok Winaya through training in handling waste disposal becomes an economic value for the residents of the male boarding house. This male boarding house is a boarding house whose occupants are all male who work as students of the University of Sultan Ageng Tirtayasa. Located in the Winaya neighborhood in Panancangan Village, Cipocok Jaya District, Serang City, Banten. Implementation of service on Tuesday, August 3, 2021 for one day. The service was carried out at the men's boarding house, Pondok Winaya, RT 03, RW 03, Panancangan Village, Cipocok Jaya District, which was attended by 20 participants. The research method used is a type of qualitative research with a descriptive approach. Data collection techniques by means of observation, discussion and interviews, while the data processing technique used is an interactive technique proposed by Milles \& Huberman (1992). The results of the service obtained are that during the initial training activities, boarding house residents are given some discussion materials and enlightenment about the waste that is often disposed of which will be of economic value as well as training in sorting the types of waste. From the results of the activities, the service partners can increase the awareness of boarding children about cleanliness and beauty and can also sort out the types of waste according to their respective groups and apply a composter that will produce liquid and solid fertilizers that can be used as plant fertilizers that sell high in the Winaya environment. This activity was directly supported by the head of RT 03 and RW 03.
\end{abstract}

Keywords: empowerment, training, waste bank

\begin{abstract}
Abstrak
Dalam kegiatan pemberdayaan yang dilakukan kost putra pondok winaya dengan melalui pelatihan penanggulangan pembuangan sampah menjadi nilai ekonomis bagi penghuni kost putra tersebut. kost putra ini merupakan kost yang penghuninya laki-laki semua yang berprofesi sebagai mahasiswa Universitas Sultan Ageng Tirtayasa tersebut. Terletak di lingkungan winaya di Kelurahan Panancangan, Kecamatan Cipocok Jaya Kota Serang-Banten. Pelaksanaan pengabdian pada hari selasa 3 Agustus 2021 selama satu hari. Pengabdian dilakukan di kost putra pondok winaya RT 03, RW 03 Kelurahan Panancangan Kecamatan Cipocok Jaya yang di ikuti oleh 20 peserta. Metode penelitian yang dilakukan adalah jenis penelitian kualitatif dengan pendekatan deskriptif. Teknik pengumpulan data dengan cara observasi, diskusi dan wawancara, adapun teknik pengolahan data yang digunakan adalah teknik interaktif yang dikemukakan oleh Milles \& Huberman (1992). Hasil pengabdian yang didapatkan adalah pada saat kegiatan awal pelatihan, penghuni kost diberikan beberapa bahan diskusi dan pencerahan mengenai sampah yang sering di buang akan menjadi nilai ekonomis serta pelatihan pemilahan jenis sampah. Dari hasil kegiatan pihak mitra pengabdian dapat meningkatkan kesadaran anak kost mengenai kebesihan dan keindahan serta dapat juga memilah jenis sampah sesuai dengan kelompoknya masing-masing serta mengaplikasikan komposter yang akan menghasilkan pupuk cair dan padat yang dapat dimanfaatkan sebagai pupuk tanaman yang berjual tinggi di lingkungan winaya tersebut. kegiatan ini, didukung langsung oleh ketua RT 03 dan RW 03.
\end{abstract}

Kata Kunci: pemberdayaan, pelatihan, bank sampah

\section{PENDAHULUAN}

Kelurahan Panancangan merupakan salah satu kelurahan yang terdapat di Kecamatan Cipocok Jaya Kota Serang Provinsi Banten. Jumlah penduduk yang cukup ini akan menambah jumlah sampah di daerah tersebut. Sampah merupakan sisa atau barang buangan yang sudah tidak digunakan dan di pakai lagi oleh pemiliknya. Sampah secara umum di bagi menjadi dua yaitu sampah organik dan anorganik (Taufik, 2015). Total produksi sampah masyarakat dalam Kota Serang mencapai 70 ton per hari. Dengan perhitungan satu rumah tangga menyumbang sebanyak 0,4 kg sampah per hari. Dari total 58 ton hanya terhitung 50 ton sehari yang masuk ke TPA 
(Tempat Pembuangan Akhir), sisanya dibuang ke laut atau ke sungai dan dibiarkan menumpuk di bawah kolong rumah atau bahkan dibiarkan saja di buang kemana-mana. Anak kost merupakan penghuni yang harus menjaga kebersihan supaya nantinya bisa memperhatikan lingkungan yang bersih supaya bisa memberikan contoh nyata ke pada masyarakat.

Sampah merupakan istilah umum yang sering digunakan sebagai limbah padat. Limbah adalah sesuatu yang tidak digunakan, tidak terpakai, tidak disenangi atau sesuatu yang dibuang dan berasal dari kegiatan manusia serta tidak terjadi dengan sendirinya. Sampah dapat dipengaruhi oleh jumlah penduduk, karena semakin banyak penduduk, maka jumlah sampah akan semakin banyak pula (Sumantri, 2010). Sampah yang biasanya dibuang anak kost adalah bungkus nasi dan bekas-bekas sampah ringan misalnya botol, kaleng dan bahkan kertas. Beberapa program yang sudah dilakukan oleh pemerintah setempat, namun masih menemukan kendala, antara lain diadakannya sosialisasi tentang sampah sesuai dengan Perda No 7 tahun 2018 tentang pencegahan dan peningkatan kualitas terhadap perumahan dan pemukiman kumuh dengan beberapa upaya salah satunya adalah dengan membudayakan membuang sampah pada tempatnya dan memisahkan sampah organik dan non organik namun pada kenyataannya masih banyak sampah yang dibuang sembarangan dan sampah banyak menumpuk yang menyebabkan lingkungan menjadi kotor dan kumuh.

Program lain yang pernah dilakukan adalah dengan membuat 1000 tong sampah, namun ada kendala yaitu banyaknya tong sampah yang hilang (Nurhayani, Dearmi Artis, Parmadi, Rosmeli, Novita Ekasari, 2020). Kendala akan kesadaran lingkungan merupakan persoalan utama yang dihadapi oleh seluruh warga Kelurahan Panancangan Kecamatan Cipocok Jaya khususnya Lingkungan Winaya pada RT 03 RW 03 dan bahkan merupakan kendala yang umum terjadi di kota Serang.

Hasil wawancara dengan masyarakat sasaran di lokasi diperoleh informasi bahwa sebenarnya jumlah masyarakat yang mengerti dan faham akan kesadaran lingkungan cukup banyak dan memadai, hanya saja mereka perlu pendampingan agar bisa merealisasikan lingkungan yang lebih sehat dan tertata dengan adanya tempat pengolahan sampah atau tong sampah. Para masyarakat RT 03 dan RW 03 kecamatan Panancangan kecamatan Cipocok Jaya Kota Serang sasaran yang tergabung dalam kelompok mitra dan Karang Taruna mengungkapkan bahwa sebagian besar pemuda siap untuk turun lapangan jika ada pendampingan dari ahli. Keadaan lainnya ialah mengenai lokasi pengolahan sampah. Masyarakat kesulitan dalam menentukan lokasi yang tepat dan ideal untuk kriteria tempat yang tepat untuk dijadikan tempat pengolahan sampah. Lokasi untuk pengolahan sampah didaerah sekitar sudah penuh dengan penghuni rumah sehingga masyarakat membuang sampah di pinggir-pinggir jalan pada waktu malam hari sehingga menimbulkan bauh yang tidak sedap.

Sampah merupakan permasalahan yang kini marak dihadapi oleh semua masyarakat sekitar. Sampah ini berkembang seiring bertambahnya jumlah penduduk dan meningkatnya aktivitas-aktivitas pembangunan yang dilakukan oleh masyarakat. Meningkatnya volume sampah ini berkembang secara eksponsial yang belum dibarengi dengan peningkatan pendapatan Pemerintah Daerah yang sepadan untuk meningkatkan sampah kota. Untuk mengatasi persoalan sampah, perlu dilakukan perubahan paradigma yang memandang sampah sebagai sumber daya yang memiliki nilai ekonomis dan dapat dimanfaatkan. Yang semula hanya sekedar mengumpulkan, mengangkut dan membuang sampah ke TPA berganti menjadi pengelolaan sampah dengan menerapkan $3 \mathrm{R}$ (Reduce, Reuse, Recycle).

Adapun beberapa jenis sampah baik organik maupun unorganik yang cukup banyak terutama di daerah perkotaan yang masih kurang untuk lahan penempatan sampah, sehingga menimbulkan persoalan kalau sampah tidak segera di tangani, tidak hanya menganggu pemandangan kampung juga permasalaham kesehatan pada masyarakat. Kumpulan sampah tidak dapat dihentikan, tetapi kita sebagai salah satu masyarakat bisa mengkelola atau mengurangi terjadinya penumpukan sampah itu dengan baik. Pembiayaan dalam pengelolaan sampah ini harus secara efektif dikelola oleh Pemerintah Daerah. Karena paada umumnya, 
pengelolaan sampah ini memerlukan anggaran yang sangat besar. Anggaran ini digunakan untuk biaya teknik operasional dari pengumpulan, pengangkutan dan pengolahan sampah sampai di tempat pembuangan akhir (Mulyadi, P. Haryoso, Ridwan Wahyudi, 2020). Pengelolaan sampah sampai saat ini hanya dipandang sebagai tanggung jawab pemerintah semata.

Masyarakat Indonesia memiliki pemikiran sebagai pihak yang dilayani saja, karena mereka semua sudah merasa cukup hanya dengan membayar uang pajak sampah saja sehingga selanjutnya menjadi tanggungjawab pemerintah. Pengelolaan sampah di Indonesia ini sudah dibagi menjadi 5 (lima) komponen sub sistem yang saling mendukung. Komponen tersebut meliputi teknis operasional, pembiayaan, organisasi dan manajemen, peraturan (hukum/legalitas) dan peran serta masyarakat. Kelima komponen tersebut saling terkait dan harus berjalan secara terpadu dalam menciptakan pengelolaan sampah yang efektif dan efisien. Langkah penanganan sampah yang lainnya adalah diadakannya pendirian bank sampah yang sekarang marak muncul disejumlah tempat. Bank sampah merupakan sistem pengelolaan sampah berbasis rumah tangga dengan memberikan ganjaran berupa uang kepada mereka yang berhasil memilah dan menyetor sampah (Sustaning, 2011).

Pengurangan sampah sudah dimulai dari masyarakat itu sendiri khususnya rumah sendiri atau tempat kost, dimana dengan cara itu bisa membudayakan membuang sampah pada tempatnya dan memisahkan sampah kering dan basah sehingga dapat di daur ulang dan bisa dimanfaatkan sehingga memiliki nilai ekonomi bagi masyarakat. Program ini sudah disosialisasikan kepada anak kost putra lingkuungan winaya pada kelurahan Panancangan Kecamatan Cipocok Jaya Kota Serang-Banten. Namun belum terlihat perubahan yang signifikan dalam mengatasi permasalahan sampah tersebut (Sri Indriyani \& Srie Isnawaty Pakaya, 2019). Permasalahan sampah di lingungan kalurahan Panancangan kecamatan Cipocok Jaya Kota Serang sangat krusial, terutama dalam hal pembuangan sampah yang cukup sulit, karena melihat kondisi lingkungan yang begitu sempit dan banyak perumahan, sehingga tempat untuk pembuangan sampah sudah tidak ada. Dampaknya tempat sampah sangat diperlukan, selain itu juga permasalahan pembuangan sampah yang begitu jauh, sehingga mengakibatkan masyarakat malas. Armada yang digunakan untuk pengambilan sampah mulai dari perumahan di ambil dengan armada gerobak sampah, kemudian baru dikumpulkan di bawah ketempat pembuangan sampah akhir, setelah terkumpul baru diangkut oleh gerobak sampah, seperti pada Gambar 1 di bawah ini.

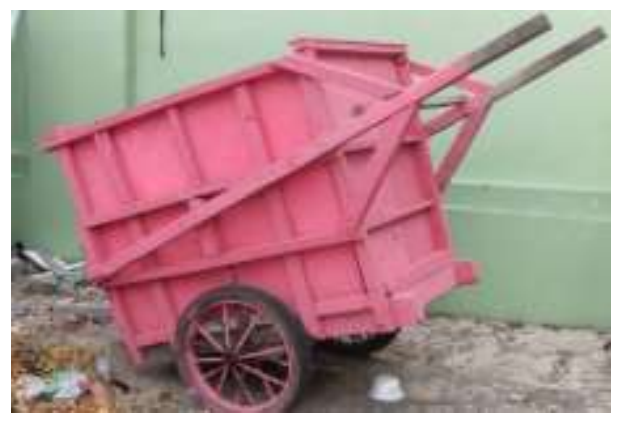

Gambar 1. Gerobak sampah

Bank sampah memiliki manfaat yang dapat dirasakan oleh masyarakat yaitu dari pembuatan kompos dapat meningkatkan produksinya dan dapat digunakan untuk pertanian yang ada di sekitar daerah selain itu dari kegiatan bank sampah masyarakat dapat berprilaku bersih dengan tidak membuang sampah sembarang dan terbiasa memafaatkan sampah untuk hal yang lebih bermanfaat Octavia dkk (2015). Andrani (2014) juga mengatakan bahwa pengelolaan sampah akan melindungi lingkungan dan membuat masyarakat bertambah sehat. Saputro (2015); Lestari, (2018) mengungkapkan bahwa pemilahan sampah sesuai dengan jenisnya akan memudahkan untuk proses daur ulang dan selanjutnya dapat dimanfaatkan pembuatan pupuk kompos pembuatan biogas dan pembuatan kertas daun methanica. Suhastyo (2017) menjelaskan 
bahwa pemanfaatan kompos selama ini belum terlalu dipahami oleh masyarakat. Padahal kompos mempunyai banyak manfaat seperti: memperbaiki struktur tanah berlempung sehingga menjadi ringan; tanah tidak berderai karena daya ikat tanah berpasir diperbanyak; menambah daya ikat tanah terhadap air dan unsur-unsur hara tanah; memperbaiki drainase dan tata udara dalam tanah dan aktivitas mikroorganisme yang merugikan dapat dikendalikan.

Ada berbagai hal yang dapat menjadikan sampah sulit utuk dikelola dengan baik, antara lain yaitu pesatnya perkembangan teknologi, meningkatnya tingkat hidup masyarakat, yang tidak disertai dengan pengetahuan tentang sampah, meningkatnya biaya operasi, pengelolaan sampah, kebiasaan pengelolaan sampah yang tidak benar, semakin sulitnya mendapatkan lahan sebagai tempat pembuangan akhir (TPA) sampah dan sulitnya mencari partisipasi masyarakat untuk membuang sampah pada tempatnya serta memelihara kebersihan (Chandra, 2012). Sampah organik merupakan sampah yang dapat diurai oleh mikroorganisme atau yang dapat membusuk seperti sampah sisa makanan, daun, sayur dan buah. Sedangkan sampah anorganik merupakan sampah yang membutuhkan waktu yang sangat lama untuk terurai, bahkan cenderung sukar terurai oleh mikroorganisme, misalnya plastik, kaca dan keleng (Sumatri, 2010).

Perkembangan sampah yang semakin banyak salah satunya dengan mingkatnya jumlah aktivitas penduduk dan diiringi dengan kurangnya kepedulian masyarakat terhadap pengelolaan sampah. Banyaknya volume sampah di Kelurahan Panancangan Kecamatan Cipocok Jaya Kota Serang-Banten. Permasalah sampah di daerah tersebut belum terselesaikan dengan baik. Berdasarkan pendekatan awal dengan mitra sehingga dapat di susun prioritas permasalahan mitra dan rencana solusinya sebagai berikut: (1) permasalah mitra dalam pengolahan sampah organik menjadi pupuk kompos padat dan cair. Komposter yang ada yang diperoleh dari bantuan pemerintah setempat tidak berfungsi lagi. (2) permasalahan mitra dalam memilah dan mengolah sampah terutama yang plastik, botol dan lainnya dan kurangnya ketrampilan masyarakat dalam membuat kerjinan yang bahannya berasal dari sampah rumah tangga sehingga menjadi barang ekonomis.

Jadi dalam UU No 18 Tahun 2008 tentang Pengelolaan Sampah menyebutkan bahwa sampah adalah sisa kegiatan sehari-hari masyarakat atau proses alam yang berbentuk padat atau semi padat berupa zat organik atau anorganik bersifat dapat terurai atau tidak dapat terurai yang dianggap sudah tidak berguna lagi dan dibuang ke lingkungan. Berdasarkan definisi ini maka sampah dapat berupa sampah yang mudah membusuk seperti sampah dapur, daun-daun kering, kotoran hewan dan sejenisnya. Sedangkan sampah yang tidak mudah terurai atau membusuk seperti sampah plastik, logam, gelas, karet dan lain-lain. Peraturan Pemerintah No 81 tahun 2012 mengamanatkan perlunya perubahan paradigma yang mendasar dalam pengelolaan sampah yaitu dari paradigma kumpul-angkut-buang menjadi pengolahan yang bertumpu pada pengurangan sampah dan penanganan sampah.

Kegiatan pengurangan sampah bermakna agar seluruh lapisan masyarakat, baik pemerintah, dunia usaha maupun masyarakat luas melaksanakan pembatasan timbulan sampah, pendauran ulang dan pemanfaatan kembali sampah atau yang lebih dikenal dengan konsep 3R. Pengertian pengelolaan sampah 3R secara umum adalah upaya pengurangan pembuangan sampah, melalui program menggunakan kembali (reuse), mengurangi (reduce), dan mendaur ulang (recycle).

Konsep tersebut dapat dijabarkan sebagai berikut: (1) Reuse (menggunakan kembali), yaitu penggunaan kembali sampah secara langsung baik untuk fungsi yang sama maupun fungsi lain. Contoh yang dapat dilakukan di rumah tangga misalnya penggunaan kembali wadah bekas botol madu untuk wadah pernak-pernik, kaleng cat untuk tempat sampah, botol plastik untuk pot bunga dan sebagainya. (2) Reduce (mengurangi), yaitu mengurangi segala sesuatu yang menyebabkan timbulnya sampah. Hal ini dapat dilakukan misalnya dengan menggunakan kantong yang tahan lama untuk belanja kebutuhan sehari-hari, menggunakan produk yang bisa diisi ulang, mengurangi pemakaian bahan sekali pakai seperti tisue dengan serbet atau sapu tangan, membawa wadah makan atau minum sendiri dan lain-lain. (3) Recycle (daur ulang), yaitu 
memanfaatkan kembali sampah setelah mengalami proses pengolahan. Hal yang dapat dikerjakan untuk konsep ini dalam skala rumah tangga diantaranya selalu memilih produk atau kemasan yang memiliki tanda bisa atau mudah didaur ulang, membuat kompos dari sampah organik yang dihasilkan, membuat sampah kaleng menjadi barang lain yang lebih bermanfaat (Nurhayani, Dearmi Artis, Parmadi, Rosmeli, Novita Ekasari, 2020).

Menurut ScienceMag, jumlah produksi sampah plastik global sejak 1950 sampai 2015 cenderung meningkat. Pada tahun 1950, produksi sampah dunia mencapai 2 ton pertahun, namun pada tahun 2015 mengalami peningkatan produksi sampah yaitu 381 juta ton pertahun. NASA merilis animasi yang menunjukkan kondisi sampah di lautan dunia. Sampah menumpuk di lima bagian samudra terbesar di Bumi. Wold Economic Forum (WEF) memprediksi pada tahun 2050, jumlah plastik dilautan akan lebih banyak. Sedangkan pada tahun 2019, di Indonesia sampah mencapai 68 juta ton. Sampah yang masih mendominasi di Indonesia adalah sampah organik sebesar $75 \%$, dilanjutkan dengan sampah plastik $13 \%$, sampah dari logam $5 \%$, sampah kertas 3\%, sampah kaca 3\% dan sampah dari kayu $1 \%$ (Kementrian Pekerjaan Umum, 2010).

Dapat diidentifikasi bahwa permasalahan dalam pengabdian ini adalah: (1) Kesadaran warga lingkungan winaya terkait manfaat lain dari pemilahan sampah. (2) Pengetahuan masyarakat tentang bank sampah belum cukup untuk membuat suatu wadah organisasi atau usaha yang dikelola dengan manajemen yang baik. (3) Belum adanya pelatihan ataupun bantuan administrasi dari pemerintah daerah terkait pengelolaan sampah.

Tujuan kegiatan ini adalah memberikan pelatihan kepada penghuni kost putra dan warga sekitar terkait pengelolaan bank sampah dan membentuk organisasi bank sampah yang dikelola dengan manajemen yang baik. Dengan terbentuknya organisasi ini diharapkan dapat menciptakan nilai tambah ekonomis sampah anorganik serta meningkatkan kesejahteraan masyarakat melalui tabungan pada bank sampah, yang di kelolah oleh masyarakar lingkungan winaya pada kelurahan Panancangan Kecamatan Cipocok Jaya Kota Serang-Banten.

\section{METODE}

Metode pemberdayaan yang digunakan adalah metode kualitatif dengan pendekatan deskriptif, dimana nantinya menemukan suatu makna dalam kegiatan pemberdayaan yang dilaksanakan di lingkungan winaya RT 03 RW 03 kelurahan Panancangan kecamatan Cipocok Jaya Kota-Serang Banten. Adapun lokasi pengabdian masyarakat mengenai pemberdayaan anak kost di lingkungan winaya RT 03 RW 03 pada kecamatan Panancangan kecamatan Cipocok Jaya Kota Serang Banten, seperti pada Gambar 2 berikut ini.

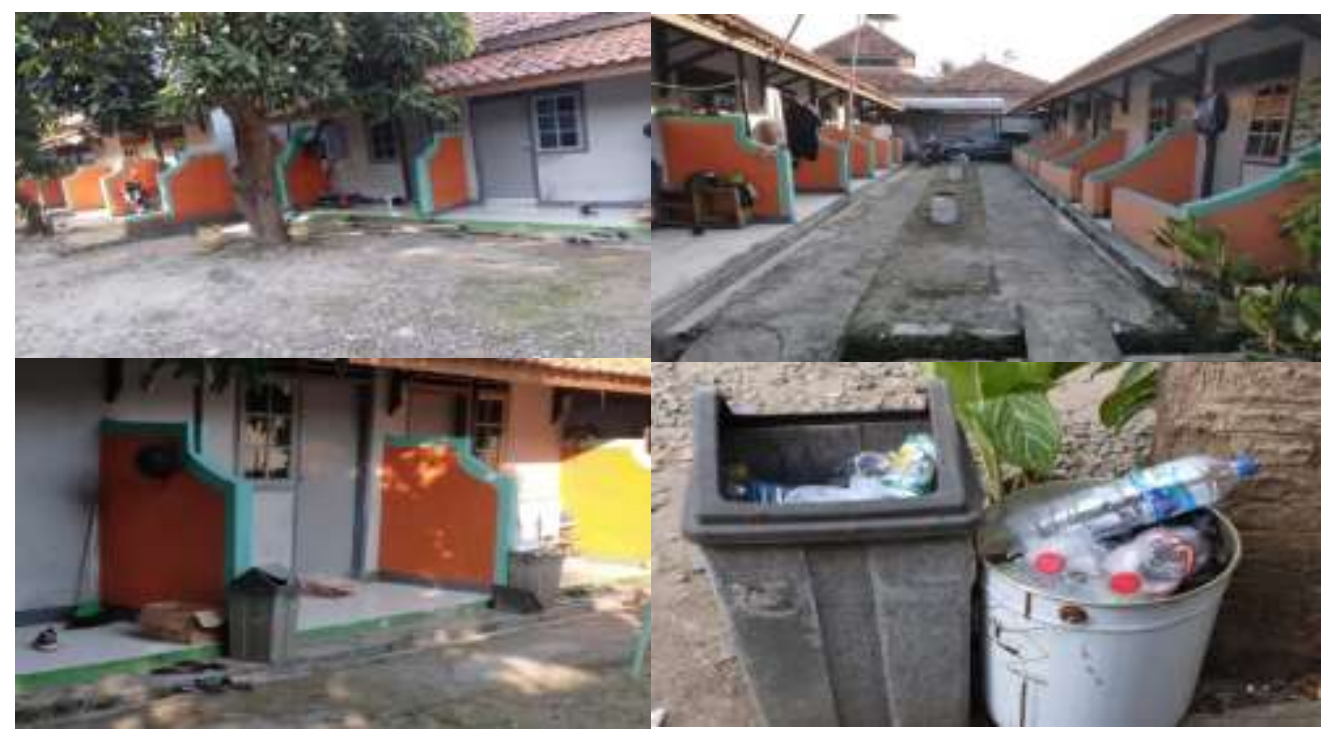

Gambar 2. Lokasi pemberdayaan anak kost lingkungan winaya 


\section{Tempat dan Waktu}

Kegiatan pemberdayaan dilakukan di lingkungan winaya kelurahan Panancangan kecamatan Cipocok Jaya pada RT 03 RW 03 Kota Serang-Banten dan dilakukan pada hari selasa tanggal 3 Agustus 2021 yang meliputi kegiatan persiapan hingga tahapan pelaporan.

\section{Tahapan dan Metode Pelaksanaan Kegiatan}

Kegiatan pemberdayaan dan pendampingan pengolahan sampah di linkungan winaya khususnya kost putra ini terdiri atas beberapa tahapan sebagai berikut: sosialisasi dan perijinan, persiapan penyuluhan, penyuluhan, praktik dan pendampingan pengolahan sampah, evaluasi hasil kegiatan.

a. Sosialisasi dan Perijinan, merupakan tahap awal kegiatan. Kegiatan ini bertujuan untuk menginformasikan kepada RT 03 RW 03 pada lingkungan winaya kelurahan Panancangan kecamatan Cipocok Jaya Kota Serang-Banten dan kelompok masyarakat sasaran mengenai rencana kegiatan. Kegiatan ini dilakukan dengan metode observasi, diskusi, dan wawancara langsung dengan ketua RT 03 RW 03 dan kelompok anak kost putra dan masyarakat desa yang hadir, sedangkan sosialisasi dengan kelompok anak kost putra serta masyarakat sasaran dilakukan di lokasi kost putra lingkungan winaya kelurahan Panancangan kecamatan Cipocok Jaya RT 03 RW 03 Kota Serang-Banten.

b. Persiapan Pendampingan, berupa alat dan bahan dipersiapkan pada kegiatan ini berupa alatalat dan bahan-bahan yang akan digunakan pada penyuluhan dan pelatihan. Alat-alat dan bahan-bahan tersebut meliputi: alat tulis, baliho kegiatan, materi kegiatan, alat-alat dan bahanbahan lainnya yang digunakan untuk praktik pengolahan sampah.

c. Pemberdayaan, dilakukan melalui metode penyampaian materi dan diskusi. Materi yang disampaikan dalam kegiatan penyuluhan ini mencakup: penyampaian materi mengenai pentingnya kebersihan lingkungan dan pemilahan sampah; strategi memilih lokasi tempat pengolahan sampah yang tepat; penyediaan prasarana dan sarana; pemilahan sampah serta pemeliharaan prasarana dan sarana pengolahan sampah. Pada kegiatan penyuluhan ini juga dilakukan sesi tanya jawab dengan anak kost putra dan masyarakat.

d. Praktik dan Pendampingan Pengolahan Sampah, kegiatan pelatihan pengolahan sampah dimulai dari pemilihan lokasi kegiatan, pelatihan pemilahan sampah organik dan anorganik, pengontrolan pengolahan sampah, dan pelatihan pemeliharaan prasarana dan sarana pengolahan sampah. Pelatihan dan praktik pengolahan sampah ini dilakukan dengan metode partisipasi aktif. Lokasi yang dipilih berdasarkan pengamatan dan kesadaran warga akan pentingnya kesadaran lingkungan yang lebih sehat dan tertata. Pelatihan praktik pengolahan sampah dilakukan dengan metode demontarsi dan praktik langsung oleh kelompok masyarakat sasaran. Pada kegiatan praktik ini, seluruh anak kost dan kelompok masyarakat sasaran dilatih dalam memilah sampah organik dan anorganik di lingkungannya masingmasing.

e. Evaluasi, yang dilakukan dalam kegiatan ini meliputi: kehadiran dan keaktifan anak kost putra dan anggota kelompok masyarakat sasaran, tingkat pengetahuannya, dan evaluasi keberlanjutan kegiatan.

Sebagai upaya menangani permasalahan sampah ditengah-tengah masyarakat ini maka solusi yang ditawarkan adalah sebagai berikut: (1) Memberikan sosialisasi kepada anak kost putra dan masyarakat melalui kegiatan pertemuan warga yang terdiri dari ibu-ibu anggota kelompok PKK tentang permasalahan sampah dan alternatif solusinya. (2) Membentuk organisasi bank sampah di lingkungan RW 03 lingkungan winaya kelurahan Panancangan kecamatan Cipocok Jaya Kota Serang-Banten. (3) Memberikan penyuluhan dan pelatihan tentang adminstrasi bank sampah kepada pengurus usaha bank sampah. (4) Pelatihan kepada anak kost dan warga sekitar terkait pembuatan produk dari sampah plastik dan sampah kering lainnya, dan (5) Pendampingan secara berkala dalam mengembangkan usaha bank sampah.

Sasaran pendampingan ini adalah anak kost putra dan warga serta pengurus PKK yang ada di lingkungan RW 03 lingkungan winaya. Metode kegiatan ini dilakukan dengan berbagai 
pendekatan yang meliputi: (1) Penyuluhan serta diskusi dengan mitra tentang permasalahan sampah serta alternatif solusinya dilakukan pada waktu yang bersamaan dengan pertemuan rutin anggota masyarakat satu bulan sekali. Penyuluhan kepada masyarakat ini dilakukan untuk memberi informasi yang akurat tentang manfaat bank sampah dan mekanisme menabung dan memperoleh hasil secara sosial maupun secara ekonomis. (2) Identifikasi sampah yang merupakan prioritas akan dikelola pada periode ini yaitu hanya sampah anorganik berupa kertas dan plastik mengingat sampah jenis ini mudah disimpan dan tidak kotor. (3) Pelatihan administrasi buku-buku penunjang bank sampah yang terdiri dari buku induk, buku rekening dan buku kas. Kegiatan pengabdian masyarakat dilaksanakan pada tanggal 3 Agustus 2021 di pondok winaya kost putra RT 03 RW 03 kelurahan Panancangan kecamatan Cipocok Jaya Kota Serang.

Metode yang digunakan dalam kegiatan ini dibagi menjadi dua tahap. Tahap pertama yaitu tim pengabdian melakukan penyuluhan mengenai pengolahan sampah berbasis 3R. Kemudian tahap kedua yaitu mendampingi anak kost putra dan masyarakat dalam praktek pengolahan sampah 3R berbasis 3R. Bahan yang disiapkan adalah sampah kertas yang akan digunakan kembali. Metode pemberdayaan yang dilakukan adalah dengan cara sebagai berikut: (1) yaitu Penyampian teori dan konsep-konsep dimana penyampaian materi yang sangat prinsip dan penting akan diberikan oleh tim pengabdian dan narasumber. Materi yang diberikan meliputi: menjelaskan tujuan dari pengabdian serta pekerjaan-pekerjaan yang akan dilakukan serta memberikan pemahaman tentang konsep-konsep yang berhubungan dengan pengabdian. Dalam kegiatan penyuluhan diberikan penjelasan tentang pengelolaan sampah, jiwa wirausaha dan pengembangan kreativitas dan inovasi dalam menghasilkan produk olahan sampah yang bernilai ekonomis. (2) Pelatihan pemilahan sampah sesuai jenisnya, dilakukan denga cara memilah sampah yang sebelumnya telah di kumpulkan oleh peserta, dimana anak kost putra dan masyarakat yang terdekat, dan (3) Pembuatan barang bernilai ekonomis. Setelah dijelaskan mengenai materi pengabdian dari tim pengabdian masyarakat dan narasumber dari Bank sampah, selanjutnya adalah peserta akan melakukan latihan langsung untuk penggunaan komposter dan pelatihan membuat barang yang bernilai ekonomis dengan bahan dasar dari sampah rumah tangga.

Teknik analisis data yang digunakan dalam pemberdayaan ini adalah analisis interaktif. Model ini ada 4 komponen analisis yaitu: pengumpulan data, reduksi data, penyajian data, dan penarikan kesimpulan. Langkah-langkah analisis data menurut Milles \& Huberman (1992), adalah sebagai berikut: (1) Pengumpulan data, yaitu mengumpulkan data di lokasi pemberdayaan dengan melakukan observasi, wawancara, dan dokumentasi dengan menentukan strategi pengumpulan data yang dipandang tepat dan untuk menentukan fokus serta pendalaman data pada proses pengumpulan data berikutnya. (2) Reduksi data, yaitu sebagai proses seleksi, pemfokusan, pengabstrakan, transformasi data kasar yang ada di lapangan langsung, dan diteruskan pada waktu pengumpulan data, dengan demikian reduksi data dimulai sejak pemberdayaan memfokuskan wilayah pemberdayaan tersebut. (3) Penyajian data, yaitu rangkaian organisasi informasi yang memungkinkan Pemberdayaan dilakukan, dan (4) Penarikan kesimpulan, yaitu dalam pengumpulan data, peneliti harus mengerti dan tanggap terhadap sesuatu yang diteliti langsung di lapangan dengan menyusun pola-pola pengarahan dan sebab akibat. Siklus analisis interaktif ditunjukkan dalam bentuk skema berikut ini.

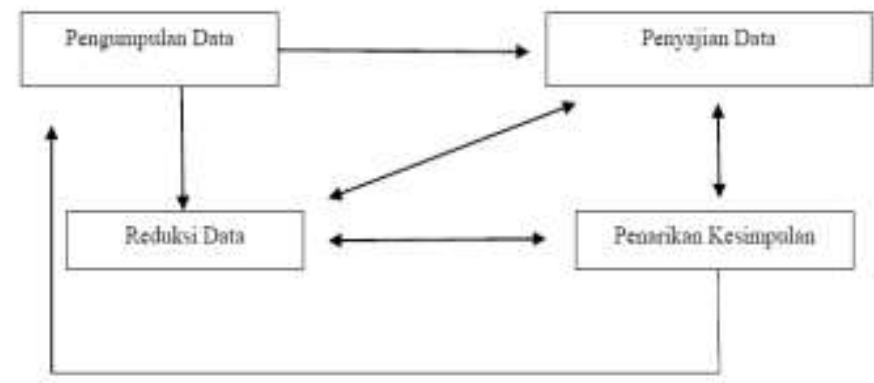

Gambar 3. Komponen-komponen analisis data model interaktif 


\section{HASIL DAN PEMBAHASAN}

Lingkungan winaya pada kelurahan Panancangan kecamatan Cipocok Jaya RT 03 RW 03 Kota Serang Banten merupakan salah satu lingkungan yang dipenuhi kost atau rumah penginapan. Lingkungan winaya ini memiliki wilayah yang sangat luas Penduduk kota Serang dari 3.675 jiwa dimana jumlah ibu rumah tangga 679 jiwa dan $30 \%$ diantaranya tidak memiliki pekerjaan. Padahal, jumlah sampah yang dihasilkan di lingkungan ini mencapai $178 \mathrm{~kg} / \mathrm{hari}$. Adanya home indutry dan Hotel di lingkungan ini mengakibatkan banyak sampah plastik maupun sampah kertas dan botol. Jumlah penduduk yang banyak ini juga mengakibatkan konsumsi barang yang besar dan akan berdampak pada sampah. Sampah yang berasal dari rumah tangga maupun sampah dari hotel. Kegiatan ini difokuskan pada salah satu lingkungan winaya kost putra RT 03 RW 03 kelurahan Panancangan Kecamatan Cipocok Jaya.

Adapun alasan pemilihan lokasi, karena RT 03 RW 03 mempunyai jumlah penduduk sekitar 150 orang dan ada beberapa penginapan seperti Hotel. Hal ini juga yang akan menambah permasalahan sampah disamping sampah dari rumah tangga. Namun sampai saat ini belum ada suatu cara atau gerakan untuk mencegah dan menangani sampah secara berkelanjutan. Yang dilakukan adalah menangani permasalahaan sampah sendiri-sendiri atau secara parsial. Sebagai contoh untuk mengelola sampah anorganik, seperti kertas, plastik, kaleng ada yang langsung membuang sampah di tempat sampah, ada yang membakarnya, namun juga ada yang dikumpulkan pada masing-masing rumah untuk selanjutnya dijual ke tukang loak. Biasanya anakanak sering melakukan pengumpulan sampah misalnya botol, kertas lalu di jual ke tukang loak, tapi ini tidak bertahan lama dikarenakan dilingkungan winaya kebanyakan pemulung dari luar.

Jenis sampah dan klasifikasinya adalah sebagai berikut: (1) Sampah organik: sampah yang terdiri dari bahan-bahan yang bisa terurai secara alamiah/biologis, seperti sisa makanan dan guguran daun. Sampah jenis ini juga biasa disebut sampah basah. (2) Sampah Anorganik Sampah anorganik: sampah yang terdiri dari bahan-bahan yang sulit terurai secara biologis. Proses penghancurannya membutuhkan penanganan lebih lanjut di tempat khusus, misalnya plastik, kaleng dan styrofoam. Sampah jenis ini juga biasa disebut sampah kering. (3) Sampah bahan berbahaya dan beracun (B3): limbah dari bahan-bahan berbahaya dan beracun seperti limbah rumah sakit, limbah pabrik dan lain-lain.

Kegiatan pelatihan dan pendampingan pengolahan sampah di Lingkungan Winaya Kost Putra diawali dengan kegiatan sosialisasi dan perijinan kepada pemerintah Kelurahan Panancangan Kecamatan Cipocok Jaya. Kegiatan ini dilakukan dengan menginformasikan kepada pemerintah desa mengenai tujuan dan rencana kegiatan. Hasil dari kegiatan diskusi tersebut menunjukkan bahwa pemerintah Kelurahan Panancangan Kecamatan Cipocok Jaya sangat antusias dan mengapresiasi kegiatan pelatihan dan pendampingan pengolahan sampah. Hal ini terlihat dari hasil wawancara yang dilakukan kepada Ketua RT 03 dan RW 03 Kelurahan Panancangan Kecamatan Cipocok Jaya yang menyatakan bahwa pemerintah Desa sangat mendukung adanya kegiatan ini guna memecahkan masalah kesadaran lingkungan dan pengolahan sampah yang selama ini dihadapi oleh mereka. Menurut Kepala RT Kelurahan Panancangan Kecamatan Cipocok Jaya, selama ini masyarakat di Kelurahan Panancangan Kecamatan Cipocok Jaya belum pernah diberikan pelatihan dan pendampingan mengenai sadar lingkungan dan pengolahan sampah (organik dan anorganik). Padahal, sebagian besar masyarakat Sindangmukti faham akan perlunya kebersihan dan kesehatan lingkungan. Oleh karena itu, kegiatan ini sangat membantu dan mendukung pemerintah desa sebagai upaya dalam meningkatkan kesadaran lingkungan.

Setelah melaksanakan kegiatan sosialisasi dan perijinan dengan pemerintah desa, selanjutnya dilakukan kegiatan sosialisasi awal dengan Anak Kost Putra Pondok Winaya dan kelompok masyarakat sasaran. Ruang lingkup diskusi awal ini meliputi rencana persiapan kegiatan, pemilihan lokasi penyuluhan, dan lokasi pengolahan sampah. Luaran dari sosialisasi awal dengan kelompok masyarakat sasaran ini adalah adanya kesepakatan mengenai waktu dan tempat pelaksanaan serta kesepahaman akan fungsi dan peran masing-masing. Untuk sementara 
tempat pembuangan sampah di kost putra Lingkungan Winaya seperti yang diperlihatkan Pada Gambar 4 di bawah ini.

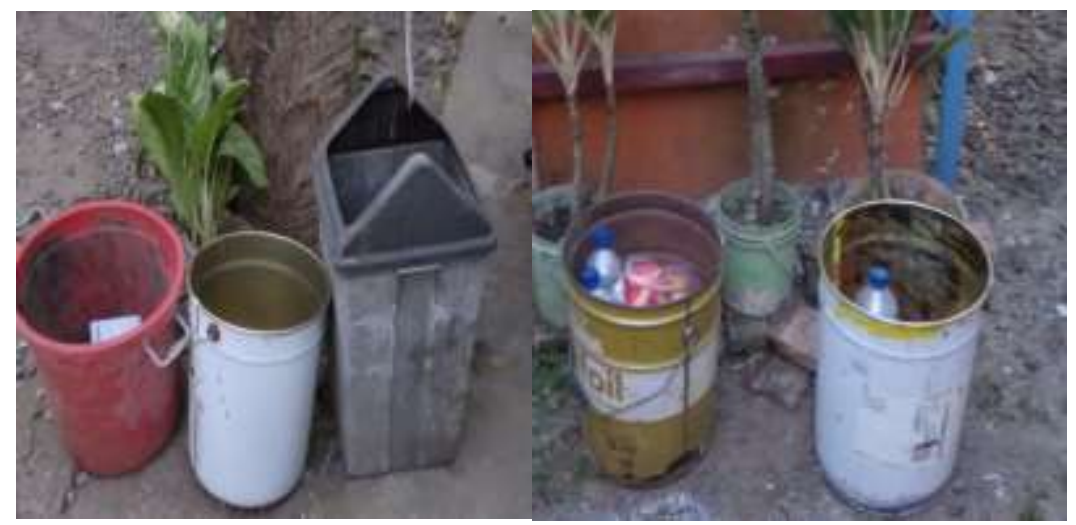

Gambar 4. Tempah sampah di kost putra Lingkungan winaya

Kegiatan penyuluhan dilaksanakan satu minggu setelah kegiatan sosialisasi awal dilaksanakan. Kegiatan ini bertujuan untuk memberikan pengetahuan dan pemahaman secara teori mengenai perlunya kesadaran lingkungan dan pengolahan sampah. Kegiatan ini dilakukan dengan metode pemaparan materi yang dilanjutkan dengan sesi tanya jawab. Beberapa pertanyaan yang muncul saat berlangsungnya sesi tanya jawab diantaranya: alat dan bahan apa saja yang harus disiapkan; bagaimana pemeliharaan prasarana dan sarana pengolahan sampah; lokasi dan tempat pengolahan sampahnya dimana; serta beberapa pertanyaan lainnya. Ada pun tempat pembuagan sampah di masyarakat seperti yang diperlihatkan pada Gambar 5 di bawah ini. Kelihatannya tempat sampah tidak dipelihara sama masyarakat sehingga pembuangan sampah terbenkalai. Sepertinya masyarakat merasa cuek dengan kondisi sampah yang ada disekeliling lingkungannya.

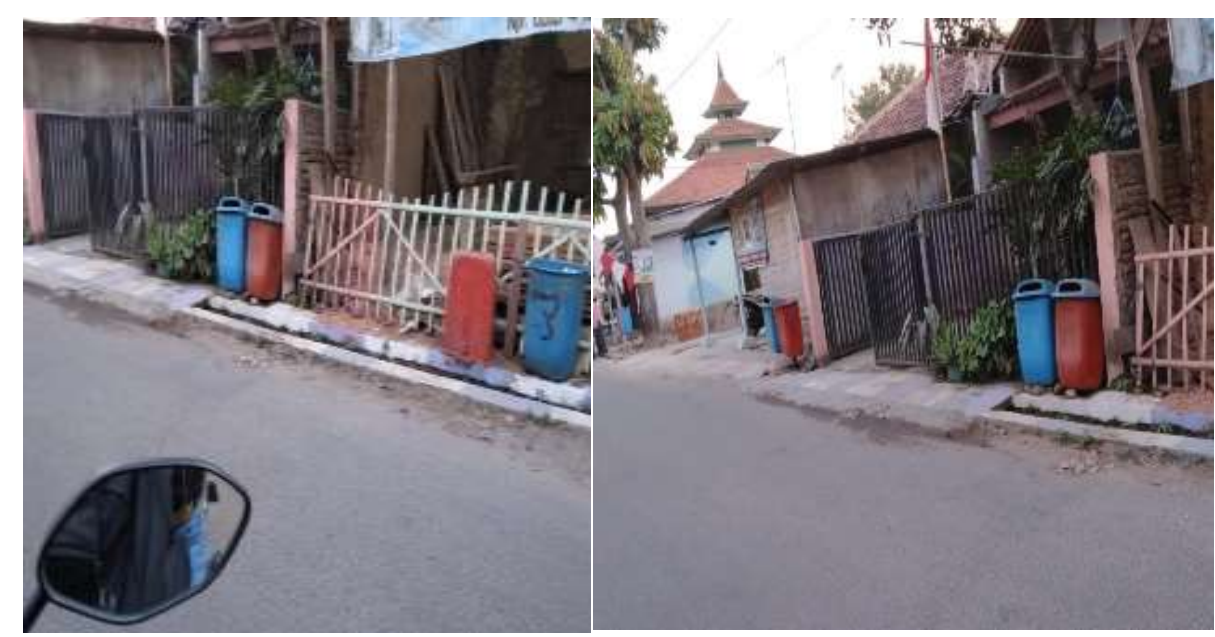

Gambar 5. Tempat sampah di Lingkungan Winaya RW 03 RT 03

Kegiatan penyuluhan ini diikuti oleh 48 orang dari kelompok masyarakat dan 20 orang anak kost putra lingkungan winaya. Pelatihan pengolahan sampah dimulai dengan pemilihan lokasi pengolahan sampah. Kagiatan ini dilakukan secara partisipasi aktif. Pertimbangan yang diambil untuk pemilihan lokasi pengolahan sampah adalah pertimbangan-pertimbangan aspek ekologi, resiko, dan sosial ekonomi. Dapat pengabdian masyarakat, sangat bermanfaat sekali kalau masyarakat memahami mengenai sampah dan bagaimana cara mengatasi sampah tersebut. bukan hanya membuang sampah di tempat yang kosong tetapi bagaimana cara masyarakat bisa mendaur ulang mengenaii sampah tersebut. kelakuan masyarakat mengenai sampah adalah 
membakar sampah dan membuang sampah ke kebun, pinggir jalan, sungai dan sebagainya seperti yang diperlihatkan pada Gambar 6 di bawah ini.

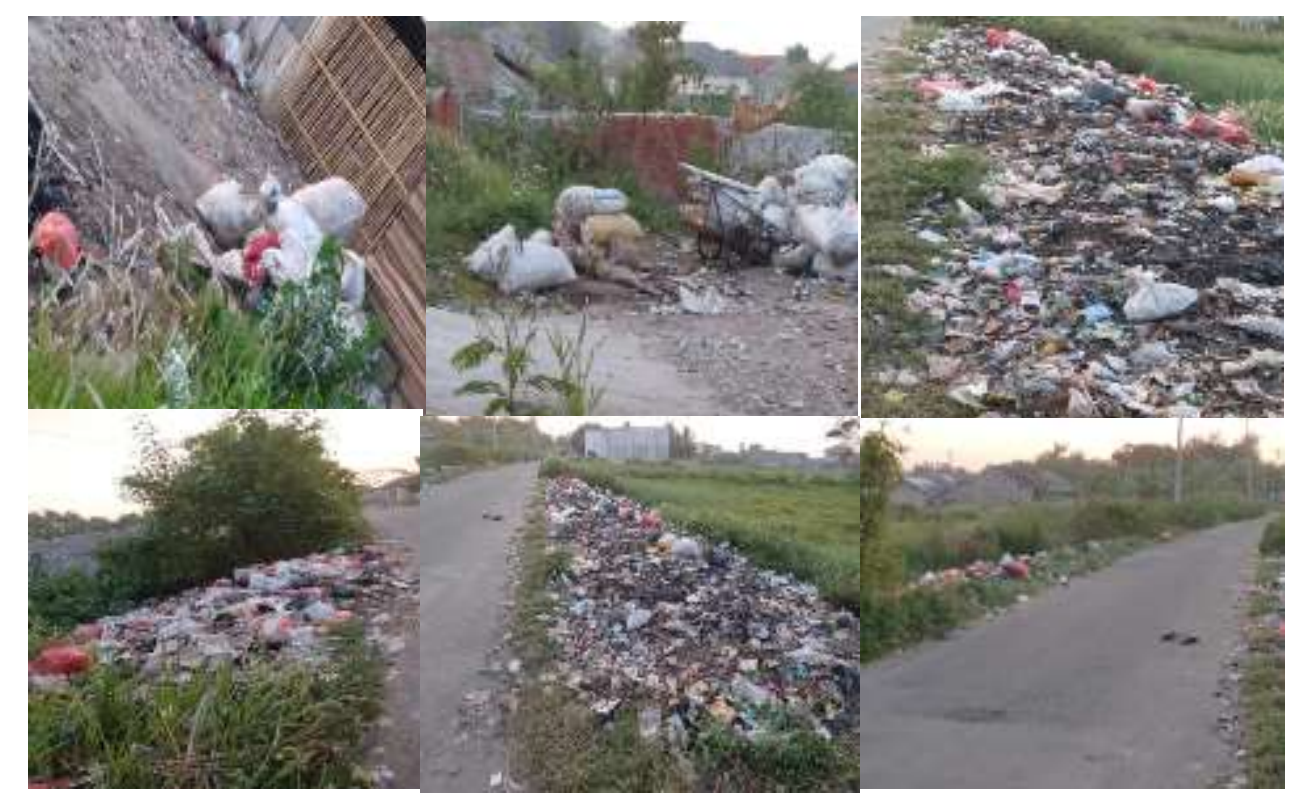

Gambar 6. Pembuangan sampah di pinggir jalan

Berdasarkan aspek ekologi, lokasi yang dipilih adalah lokasi yang memiliki lingkungan yang mendukung untuk pengolahan sampah. Hasil pengamatan kondisi lingkungan di lokasi yang sudah ditentukan menunjukkan bahwa lokasi cukup representatif sehingga ekologi lainnya tidak terganggu. Aspek resiko juga menjadi pertimbangan dalam menentukan lokasi pengolahan sampah. Berdasarkan aspek-aspek tersebut, maka dipilihlah lokasi dengan ukuran 5 x 5 m dimana lokasi ini cukup strategis dan tidak membutuhkan waktu lama dari rumah penduduk. Adapun gambaran lokasi pengolahan sampah. Setelah pemilihan lokasi, kegiatan pelatihan dilanjutkan dengan penyiapan prasarana dan sarana pengolahan sampah.

Kegiatan pengabdian masyarakat dibagi menjadi dua tahap, antara lain: (1) Tahap Pertama: penyuluhan mengenai pengolahan sampah berbasis 3R Pengetahuan adalah kesan dimana dalam pikiran manusia sebagai hasil dalam penggunaan pancaindera, dan berbeda dengan kepercayaan, takhayul, maupun penerapan-penerapan yang keliru (Soekanto, 2003). Pengetahuan membentuk sikap seseorang untuk melakukan tindakan atau perilaku. Dengan diberikannya penyuluhan tentang pengolahan sampah berbasis $3 \mathrm{R}$ bertujuan untuk meningkatkan pengetahuan anak kost putra lingkungan winaya mengenai pengolahan sampah sehingga menimbulkan kesadaran bagi anak kost putra untuk melakukan pengolahan sampah yang benar dengan pendekatan 3R. Penyuluhan dilaksanakan berbeda antara kost putri dan kost putra. Penyuluhan pengolahan sampah berbasis 3R dimulai dengan pertanyaan-pertanyaan mengenai sampah dan lingkungan sekitar. Kemudian anak kost putra diberikan materi mengenai sampah dan dampak buruk yang terjadi bila sampah tidak diolah dengan benar setelah itu baru dijelaskan mengenai pengolahan sampah berbasis 3R.

Anak kost putra di lingkungan winaya RT 03 RW 03 sangat antusias, hal ini terlihat banyak anak kost putra yang bertanya. Penyuluhan tersebut akan meningkatkan pengetahuan anak kost putra di lingkungan winaya, hal ini sesuai dengan Notoatmodjo (2007) yang mengungkapkan bahwa pengetahuan atau kognitif merupakan domain yang sangat penting untuk terbentuknya tindakan seseorang. (2) Tahap Kedua: Mendampingi anak kost putra di lingkungan winaya melakukan praktek pegolahan berbasis 3R Setelah diberikan penyuluhan, anak kost putra di lingkungan winaya melakukan praktek pengolahan sampah berbasis $3 \mathrm{R}$ didampingi tim 
pengabdian masyarakat. Sebelum menguraikan hasil yang telah dicapai pada kegiatan pengabdian masyarakat ini maka terlebih dahulu di sampaikan gambaran materi yang di jadikan dasar dalam interaksi dengan masyarakat, pemerintah dan lembaga desa lainnya.

Salah satu materi yang dapat disampaikan adalah menyangkut sampah, jenis-jenis samapah serta cara pengolahan samapah. Hal ini penting untuk disampaikan sehingga nantinya pengabdian masyarakat ini dapat menjadi referensi untuk pengabdi selanjutnya. Sampah adalah barang yang dianggap sudah tidak terpakai dan dibuang oleh pemilik atau pemakai sebelumnya, tetapi bagi sebagian orang masih bisa dipakai jika dikelola dengan prosedur yang benar (Panji Nugroho, 2013). Pemberiam penyuluhan diharapkan akan merubah sikap yang baik sehingga menimbulkan perilaku yang baik pula. Hal ini sesuai dengan penyataan Elizabeth (2017), menyatakan bahwa santri mulai menyadari arti pengelolaan sampah yang benar setelah diberikan penyuluhan, karena bila tidak dilakukan dengan benar, maka akan menimbulkan pencemaran untuk lingkungan sekitar pesantren. Pengabdian dilakukan di rumah salah satu warga di Jalan Gang Kelinci di Kelurahan Panancangan Kecamatan Cipocok Jaya, diikuti oleh 6 peserta. Hasil kegiatan pengabdian kepada mayarakat tentang pemberdayaan masyarakat melalui pelatihan sampah menjadi nilai ekonomis dan bantuan teknis antara lain adalah berupa pengetahuan tentang sampah dan permasalahannya, pengelolaan sampah berdasarkan konsep $3 R$, pengetahuan peserta tentang jenis sampah dan pengelompokkannya serta keterampilan peserta dalam membuat pupuk kompos.

Dengan adanya pengabdian seperti ini, mudah-mudahan masyarakat sadar akan pentingnya mengenai sampah, oleh karena itu perlu adanya pemberdayaan atau pelatihan masyarakat untuk memberikan suatu pengetahuan pengelolaan sampah tersebut. Peserta pemberdayaan memahami pengelompokkan jenis sampah dan direncanakan akan dibentuk kelompok-kelompok kecil sebagai awal dari proses pengumpulan sampah rumah tangga. Peserta pengabdian sangat mendukung kegiatan ini untuk meningkatkan kepedulian masyarakat terhadap kebersihan Meski selama ini sudah terpasang imbauan tidak buang sampah sembarangan, tetapi hal itu tidak efektif karena masyarakat masih belum sadar dalam menjaga kebersihan lingkungannya. Tumpukan sampah rumah tangga, mulai dari plastik bekas makanan dan popok bayi yang masih berserakan mengotori disekitar rumah warga dan pinggir jalan dan di saat musim hujan akan tergenang oleh air. Selanjutnya setelah di lakukan pemilahan barangbarang bekas sesuai dengan kelompoknya masing-masing maka akan dapat di bentuk bank sampah.

Bank sampah merupakan wadah untuk menampung sampah agar tidak hanya terbuang sia-sia tetapi juga ditukar dengan manfaat daur ulang dan uang. Disaat pengabdian dilaksanakan salah satu peserta tim pengabdian merupakan direktur Bank Sampah Bangkitku, sehingga peserta pengabidan dapat bertanya langsung dan sangat bersemangat berkonsultasi tentang tahapantahapan pembentukan bank sampah. Bank sampah juga dapat dijadikan solusi untuk mencapai pemukiman yang bersih dan nyaman bagi warganya. Dengan pola ini maka warga selain menjadi disiplin dalam mengelola sampah juga mendapatkan tambahan pemasukan dari sampah-sampah yang dikumpulkan. Permasalahan sampah merupakan hal yang krusial (sulit terselesaikan). Bahkan, dapat diartikan sebagai masalah kultural/kebiasaan karena dampaknya mengenai berbagai sisi kehidupan, terutama di kota besar. Mengutip dari buku Panduan Membuat Pupuk Organik Cair (Panji Nugroho, 2013), setiap harinya sekitar 6000 ton sampah dihasilkan di kota Jakarta.

Pengelolaan sampah diantaranya dapat dimanfaatkan menjadi kompos organik yang didalamnya terkandung unsur hara yang dibutuhkan tanaman (Panji Nugroho, 2013), perbaikan struktur tanah dan zat yang dapat mengurangi bakteri yang merugikan dalam tanah. Pupuk organik biasanya tidak meninggalkan residu / sisa dalam tanaman sehingga hasil tanaman akan aman bila dikonsumsi (Tresna Sastrawan, 2014). Jenis-jenis sampah Menurut Panji Nugroho dalam buku Panduan Membuat Pupuk Kompos cair (2013), jenis-jenis sampah dapat digolongkan menjadi beberapa jenis, antara lain: 
a. Sampah alam yaitu sampah yang ada oleh proses alam yang dapat di daur ulang alami, seperti halnya daun-daunan kering di hutan yang terurai menjaditanah. Di luar kehidupan liar, sampah-sampah ini dapat menjadi masalah, misalnya daun-daun kering di lingkungan pemukiman.

b. Sampah manusia, (human waste) adalah istilah yang biasa digunakan terhadap hasil-hasil pencernaan manusia, seperti feses dan urin. Sampah manusia dapat menjadi bahaya serius bagi kesehatan karena dapat digunakan sebagai vektor (sarana perkembangan) penyakit yang disebabkan virus dan bakteri. Salah satu perkembangan dalam mengurangi penularan penyakit melalui sampah manusia dengan cara hidup yang higenis dan sanitasi. Termasuk didalamnya adalah perkembangan teori penyaluran pipa (plumbing).

c. Sampah konsumsi Sampah konsumsi merupakan sampah yang dihasilkan oleh manusia(pengguna barang), dengan kata lain adalah sampah hasil konsumsi sehari-hari. Ini adalah sampah yang umum, namun meskipun demikian, jumlah sampah kategori ini masih jauh lebih kecil dibandingkan sampah-sampah yang dihasilkan dari proses pertambangan dan industri.

d. Sampah Industri Sampah industri adalah bahan sisa yang dikeluarkan akibat proses proses industri. Sampah yang dikeluarkan dari sebuah industri dangan jumlah yang besar dapat dikatakan sebagai limbah. Berikut adalah gambaran dari limbah yang berasal dari beberapa industri, yaitu: (1) Limbah industri pangan (makanan), sebagai contoh yaitu hasil ampas makanan sisa produksi yang dibuang dapat menimbulkan bau dan polusi jika pembuangannya tidak diberi perlakuan yang tepat. (2) Limbah Industri kimia dan bahan bangunan, sebagai contoh industri pembuat minyak pelumas (OLI) dalam proses pembuatannya membutuhkan air skala besar, mengakibatkan pula besarnya limbah cair yang dikeluarkan ke lingkungan sekitarnya. air hasil produksi ini mengandung zat kimia yang tidak baik bagi tubuh yang dapat berbahaya bagi kesehatan. (3) Limbah industri logam dan elektronika, bahan buangan seperti serbuk besi, debu dan asap dapat mencemari udara sekitar jika tidak ditangani dengan cara yang tepat.

Penyelesaian masalah sampah tidak hanya dilakukan dengan mengandalkan petugas kebersihan saja. Seluruh lapisan masyarakat harus membantu pemerintah untuk bergerak bersama dalam menangani masalah sampah dengan penerapan sistem $3 \mathrm{R}$ (reduce, reuse, recycle) dalam wujud bank sampah di Anak kost putra di lingkungan winaya. Sistem ini berguna untuk mengelola sampah dengan menampung, memilah, dan mendistribusikan sampah kefasilitas pengolahan sampah dalam hal ini ke TPS, sehingga sampah di tempat pembuangan akhir bisa berkurang bahkan bisa bernilai ekonomis. Adapun tempat pembuangan sampah yang terakhir seperti pada Gambar 7 di bawah ini.

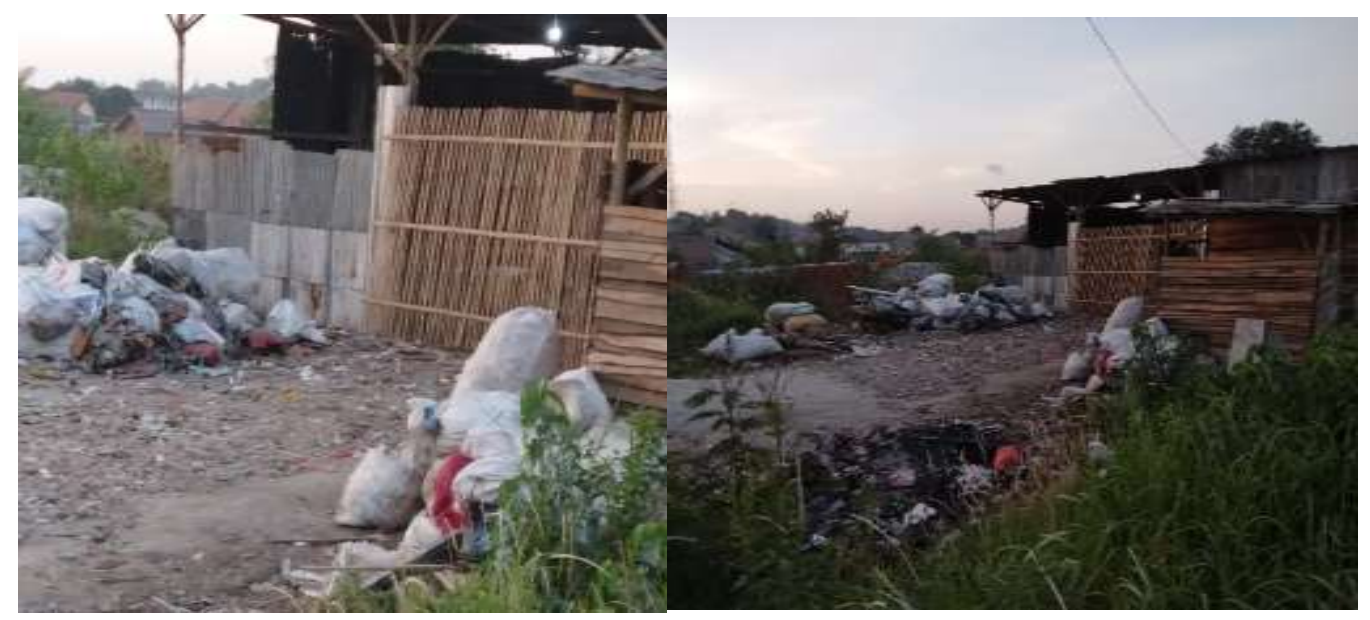

Gambar 7. Tempat Penjualan sampah 
Untuk pengelolaannya sudah ditetapkan beberapa orang sebagai petugas dan pengelola bank sampah yag bertanggung jawab dalam pengoperasiannya dalam hal ini Anak kost putra di lingkungan winaya yang telah dibuatkan surat keputusan pada tahun 2020 oleh Ketua RT 03. Adapun administrasi kelengkapan yang harus dimiliki oleh bank sampah adalah sebagai berikut: (1) Buku tabungan untuk anggota, (2) Buku daftar anggota, (3) Buku induk besar keuangan bank sampah, (4) Buku rekap penyetoran anggota, dan (5) Daftar hadir anggota yang menyetorkan sampah. Pada prakteknya susunan pengurus pengelola bank sampah yang telah ditetapkan merupakan pengelola TPS $3 \mathrm{R}$ yang dilaksanakan oleh Anak kost putra di lingkungan winaya adalah sebagai berikut:
Ketua: Irwan Sawan
Sekertaris: Asra Alimin
Bendahara: Jundi Pangkalele
Seksi Administrasi Dan Pencatatan: Makbul Buto
Seksi Pengawasan: Muh. ABD Kadir Syam
Seksi penyuluhan: Irwanto Syamsualam
Seksi Pemasaran: Helmy Panda
Seksi penimbangan Dan pengepakan: Halimin

Menurut Panji Nugroho (2013), berbagai cara yang dapat mengurangi efek negatif dari sampah, antara lain: (a) Penumpukan Metode ini dilakukan dengan cara menumpuk sampah samapai membusuk, sehingga dapat menjadi kompos. (b) Pembakaran Pembakaran merupakan cara yang sering dilakukan, bahka diberbagai TPA metode ini kerap dipakai pemerintah, kelemahan metode ini adalah tidak semua sampah dapat habis dibakar. (c) Sanitary Landfill Metode ini juga kerap digunakan pemerintah, cara penerapannya adalah dengan membuat lubang baru untuk mengubur sampah, dan (d) Pengomposan Cara ini sangat dianjurkan karena berdampak positif dan menghasilkan barang bermanfaat dari sampah yang berguna bagi lingkungan dan alam.

\section{KESIMPULAN}

Berdasarkan hasil dan pembahasan di atas dapat disimpulkan bahwa kegiatan ini berlangsung dengan baik sesuai dengan yang direncanakan. Responden dalam pengabdian ini sangat antusias dan berpartisifasi aktif dalam melaksanakan kegiatan. Kegiatan-kegiatan yang telah dilakukan, antara lain:

a. Sosialisasi dan pelatihan pengelolaan sampah menjadi bahan atau barang bernilai ekonomis dan pembentukan bank sampah.

b. Sosialisasi Pengelolaan Sampah dan Pembentukan Bank Sampah di kost putra lingkungan winaya RT 03 RW 03 kelurahan Panancangan Kecamatan Cipocok Jaya Kota Serang Banten.

c. Pembentukan bank sampah.

d. Pembuatan tempat sampah.

\section{DAFTAR PUSTAKA}

Andarani, A dan Naohiro Goto. 2014. Potential e-waste generated from households in Indonesia using material flow analysis. Springer Japan No 16: 306-320.

Chandra, Budiman. 2012. Pengantar Kesehatan Lingkungan. Penerbit buku Kedokteran. EGC.

Elizabeth, Misbah Zulfa. 2017. Program Pengelolaan Kebersihan Lingkungan di Pesantren. DIMAS. Volume 17 Nomor 1.

Kementrian Pekerjaan Umum. 2010. Modul Sampah Berbsis 3R.

Lestari, Novi dan Dicky. 2018. ibM Bank Sampah Desa Mojorejo Kota Batu. Jurnal Pengabdian Kepada Masyarakat, Volume 1 Nomor 1, Hal, 23-27.

Miles, M. B \& Huberman A. M. 1992. Analisis Data Kualitatif. Terjemahan oleh Tjetjep Rohendi Rohidi. 1992. Jakarta: Penerbit Universitas Indonesia. 
Mulyadi, P. Haryoso, Ridwan Wahyudi. 2020. Pembentukan Program Bank Sampah Guna Membantu Pemerintah Daerah Dalam Menangani Permasalahan Sampah di Kelurahan Nusukan Kota Surakarta. WASANA NYATA: Jurnal Pengabdian kepada Masyarakat Vol.4, No.1 April (2020); p.64-71; https://e-journal.stie-aub.ac.id/index.php/wasana_nyata. HIm 64-71.

Notoatmodjo, S. 2007. Kesehatan Masyarakat (Ilmu dan Seni). Rineka Cipta. Jakarta.

Nurhayani, Dearmi Artis, Parmadi, Rosmeli, Novita Ekasari. 2020. Pemberdayaan Masyarakat Melalui Pelatihan Sampah Menjadi Nilai Ekonomis dan Bantuan Teknis Di Kelurahan Tungkal II Kabupaten Tanjung Jabung Barat. Jurnal Karya Abdi P-ISSN:2580-1120 Volume 4 Nomor 3 Desember 2020 E-ISSN:2580-2178. Hlm. 531-535.

Octavia, Ade dkk. 2015. Pemberdayaan Masyarakat Melalui Optimalisasi Program Bank Sampah dengan Bantuan Tekhnis dan Manajemen Usaha pada KSM Aneka Limbah dan KSM Maidanul Ula Kota Jambi. Jurnal Pengabdian pada Masyarakat, Volume 30 Nomor 3, Hal. 40-48.

Panji Nugroho. 2013. Sosialisasi Sampah Organik Dan Non Organik Serta Pelatihan Kreasi Sampah. Seri Pengabdian Masyarakat Jurnal Inovasi Dan Kewirausahaan Volume 4 No. 1, Januari 2015 Halaman 68-73.

Peraturan Pemerintah Republik Indonesia Nomor 81 Tahun 2012 tentang Pengelolaan Sampah Rumah Tangga dan Sampah Sejenis Rumah Tangga.

Saputro, Yuso dkk. 2015. Pengelolaan Sampah Berbasis Masyarakat Melalui Bank Sampah. Indonesian Journal of Conservation, Volume 4 Nomor 1, Hal 83-94.

Soekanto, S. 2003. Sosiologi Suatu Pengantar., CV Rajawali. Jakarta.

Sri Indriyani S Dai dan Srie Isnawaty Pakaya. 2019. Pemberdayaan Masyarakat Melalui Pengelolaan Sampah Menjadi Nilai Ekonomis dan Pembentukan Bank Sampah di Desa Pentadu Timur Kecamatan Tilamuta Kabupaten Boalemo. Jurnal Ilmiah Pengabdhi. Volume 5 No 2, Oktober 2019 http://journal.trunojoyo.ac.id/pangabdhi ISSN: 2477-6289.

Suhastiyo, Arum. 2017. Pemberdayaan Masyarakat Melalui Pelatihan Pembuatan Pupuk Kompos. Jurnal Pengabdian dan Pemberdayaan Masyarakat, Volume 1 Nomor 2, Hal. 63-68.

Sumantri, Arif. 2010. Kesehatan Lingkungan Edisi Ketiga. Kencana Prenada Media Group.

Sustaning, 2011. Bijak \& Cerdas Mengolah Sampah, Membuat Kompos Dari sampah Rumah Tangga. Jakarta: Agro Media Pustaka.

Taufiq, A, Maulana, M, F. 2015. Sosialisasi Sampah Organik Dan Non Organik Serta Pelatihan Kreasi Sampah. Seri Pengabdian Masyarakat Jurnal Inovasi Dan Kewirausahaan Volume 4 No. 1, Januari 2015 Halaman 68-73.

Undang-Undang No. 18 Tahun 2008 tentang Pengelolaan Sampah. 